RESEARCH

\title{
The Marine Bacterium Pseudoalteromonas haloplanktis Has a Complex Genome Structure Composed of Two Separate Genetic Units
}

\author{
Brian D. Lanoil, ${ }^{1}$ Lynda M. Ciuffetti, ${ }^{2}$ and Stephen J. Giovannoni ${ }^{1,3}$ \\ Departments of ${ }^{1}$ Microbiology and ${ }^{2}$ Botany and Plant Pathology, Oregon State University, \\ Corvallis, Oregon 97331
}

\begin{abstract}
The genome size of Pseudoalteromonas haloplanktis, a ubiquitous and easily cultured marine bacterium, was measured as a step toward estimating the genome complexity of marine bacterioplankton. To determine total genome size, we digested $P$. haloplanktis DNA with the restriction endonucleases Notl and Sfil, separated the fragments using pulsed-field gel electrophoresis (PFGE), and summed the sizes of the fragments. The $P$. haloplanktis genome was $3512 \pm 112 \mathrm{~kb}$ by Notl digestion and $3468 \pm 54.1 \mathrm{~kb}$ by Sfil digestion. P. haloplanktis is also shown to have a complex genome structure, composed of two large replicons of $\sim 2700$ and $800 \mathrm{~kb}$. Three pieces of evidence support this conclusion: (1) Two separate bands are always seen in PFGE of undigested $P$. haloplanktis DNA; (2) restriction digests of the larger band are missing a band of $\sim 650 \mathrm{~kb}$ compared with restriction digests of total genomic DNA; and (3) a 16S rDNA probe hybridized to the larger replicon but not to the smaller. To our knowledge, $P$. haloplanktis is the first marine bacterium shown to have a complex genome structure.
\end{abstract}

The structure and size of bacterial genomes are becoming increasingly important to microbial ecologists. This interest in bacterial genomics was stimuated in part by the cloning of $16 \mathrm{~S}$ rRNA genes from nucleic acids extracted from environmental samples, which is now used routinely as a method for assessing microbial diversity (Ammann et al. 1995). These studies resulted in the recognition that uncultured species are important components of many natural ecosystems. The first cloning and sequencing of large genomic DNA fragments from an uncultured species were reported recently (Stein et al. 1996). Although the information obtained by random sequencing of this fragment failed to identify the physiology of the organism, in principle, genomic DNA sequencing can be used to understand the physiology of an uncultured microbe. Such attempts to link physiologically relevant genes with phylogenetically informative genes, such as $16 \mathrm{~S}$ rRNAs, depend on assumptions about the complexity of bacterial populations, the size distributions of bacterial genomes, and the organization of bacterial chromosomes in natural systems. Similar considerations apply to genetic

${ }^{3}$ Corresponding author.

E-MAIL giovanns@bcc.orst.edu; FAX (541) 737-0496. measurements of microbial diversity; Farrelly and colleagues (1995) recently emphasized that the sizes and copy numbers of genomes can greatly affect the frequencies of $16 \mathrm{~S}$ rDNAs in natural populations.

The possibility that bacterial genomes might be reconstructed from contiguous, large DNA fragments cloned from natural populations relies on the assumption that bacterial genomes are single circular chromosomes. However, with the discovery of two separate circular chromosomes in Rhodobacter sphaeroides 2.4.1 (Suwanto and Kaplan 1989, 1992), the concept of the single circular chromosome that contains the entire genome of the prokaryote has been revised. A number of prokaryotes have complex genome organizations, including multiple chromosomes (Suwanto and Kaplan 1989, 1992; Zuerner 1991; Allardet-Servent et al. 1993; Michaux et al. 1993; Zuerner et al. 1993; Cheng and Lessie 1994) and large megaplasmids (Mergeay et al. 1985; Friedrich et al. 1986; Bancroft et al. 1989; Sobral et al. 1991; Lopez-Garcia et al. 1994; Muro-Pastor et al. 1994). The extent of such complexity has been largely unexplored, and, in particular, the genome structure of marine bacteria has, until now, been uncharacterized.

Marine bacterioplankton have served as a 
testbed for the development of methods for studying complex mixtures of nucleic acids derived from environmental samples (Giovannoni et al. 1990; Stein et al. 1995). Significantly, in this regard, it has been suggested that marine bacterioplankton have unusually small genomes (Robertson and Button 1989; Button et al. 1993). One approach to addressing this issue is the measurement of the genome sizes of model cultured marine bacterioplankton. There are a few species of bacterioplankton that have been cultured and are also commonly found in rDNA libraries from natural systems (Mullins et al. 1995). These are, therefore, good models for examining genome size in predominant bacterioplankton. Our model organism, Pseudoalteromonas haloplanktis (formerly Alteromonas haloplanktis; Gauthier et al. 1995), is an obligately aerobic gram-negative rod that is readily isolated from both coastal and open ocean water columns (Baumann et al. 1984). P. haloplanktis has also been found in both Atlantic and Pacific Ocean study sites by rDNA analysis, suggesting that it is a widespread and numerically important species in natural systems (Mullins et al. 1995).

Here $P$. haloplanktis is shown to have a moderate-sized genome, measured by pulsed-field gel electrophoresis (PFGE) to be $-3500 \mathrm{~kb}$. We also report that $P$. haloplanktis has a complex genome structure, composed of two large, chromosomesized replicons: The larger is $\sim 2700 \mathrm{~kb}$ and the smaller $\sim 800 \mathrm{~kb}$. These results indicate that it would not be possible to reconstruct the genome of $P$. haloplanktis by assembling contiguous large DNA fragments cloned from environmental DNA samples.

\section{RESULTS}

\section{PFGE of Intact $P$. haloplanktis Genomic DNA}

We examined the intact genome of $P$. haloplanktis and compared it with that of Escherichia coli. For this purpose, we used PFGE, specifically, the contour-clamped homogenous electric field (CHEF) method. During the optimization of CHEF protocols, an ancillary band of $\sim 800 \mathrm{~kb}$ was always observed in preparations of $P$. haloplanktis genomic DNA but never in the preparations of $E$. coli genomic DNA. To examine this phenomenon further, we optimized two different run protocols designed to adequately separate this band from the larger replicon (Fig. 1 a,b). The extra band was observed under all conditions examined and dur-

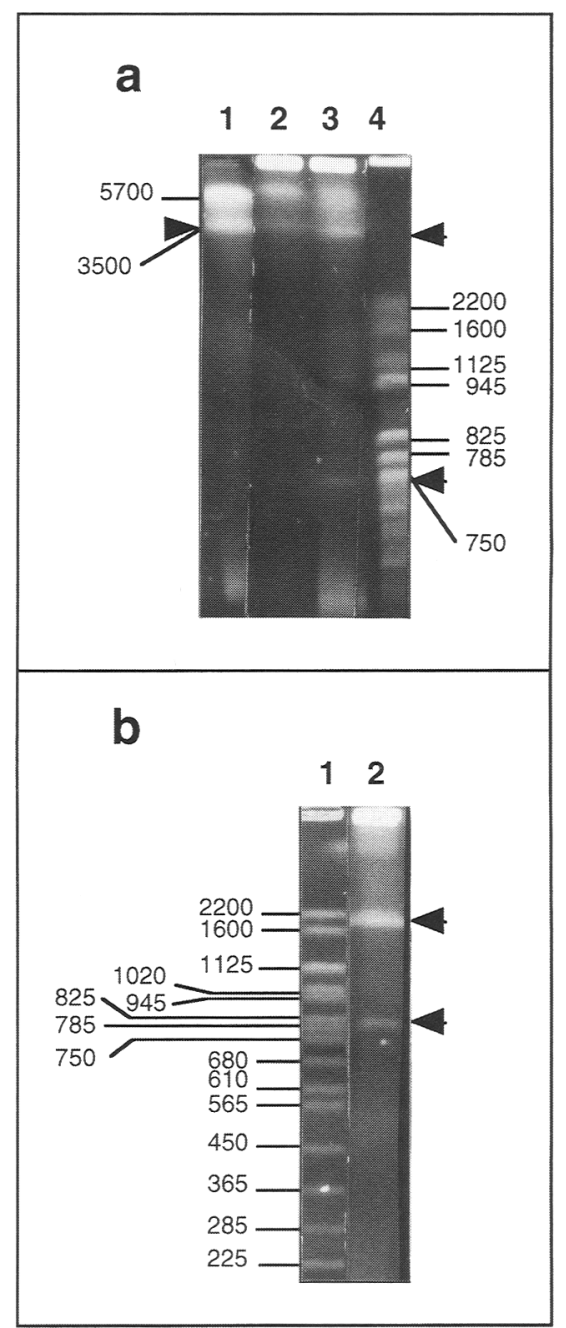

Figure 1 Undigested genomic DNA separated by two different CHEF protocols. Size markers are in kb. Arrowheads indicate linearized genomic elements. (a) PFGE protocol A (Table 1). Arrowhead at left refers to lane 2; at right, lane 3. (Lane 1) S. pombe chromosomal DNA (size standard); (lane 2) E. coli AB1157 (high concentration); (lane 3) P. haloplanktis (one-fifth high concentration); (lane 4) S. cerevisiae chromosomal DNA (size standard). (b) PFGE protocol B (Table 1). (Lane 1) S. cerevisiae chromosomal DNA (size standard); (lane 2) P. haloplanktis (one-fourth high concentration).

ing all steps of the optimization process. No bands smaller than the chromosomal DNA were ever seen for E. coli genomic DNA.

The relative ethidium bromide fluorescence intensity for the larger $P$. haloplanktis replicon was 14 -fold higher than for the smaller replicon-4.1-fold higher than expected from the size 
LANOIL ET AL.

difference alone, assuming a one-to-one stoichiometry.

\section{Sizing of the P. haloplanktis Genome}

P. haloplanktis genomic DNA was digested with the restriction endonucleases NotI (Fig. 2a,b) and Sfil (Fig. 2 c,d). NotI digestions yielded 16 observable DNA fragments ranging from $24.7 \mathrm{~kb}$ to $711 \pm 8.7 \mathrm{~kb}$. Sfil cut the DNA into 20 fragments ranging from $31.0 \mathrm{~kb}$ to $586 \pm 18.1 \mathrm{~kb}$ (Table 2 , below). No single set of conditions were able to

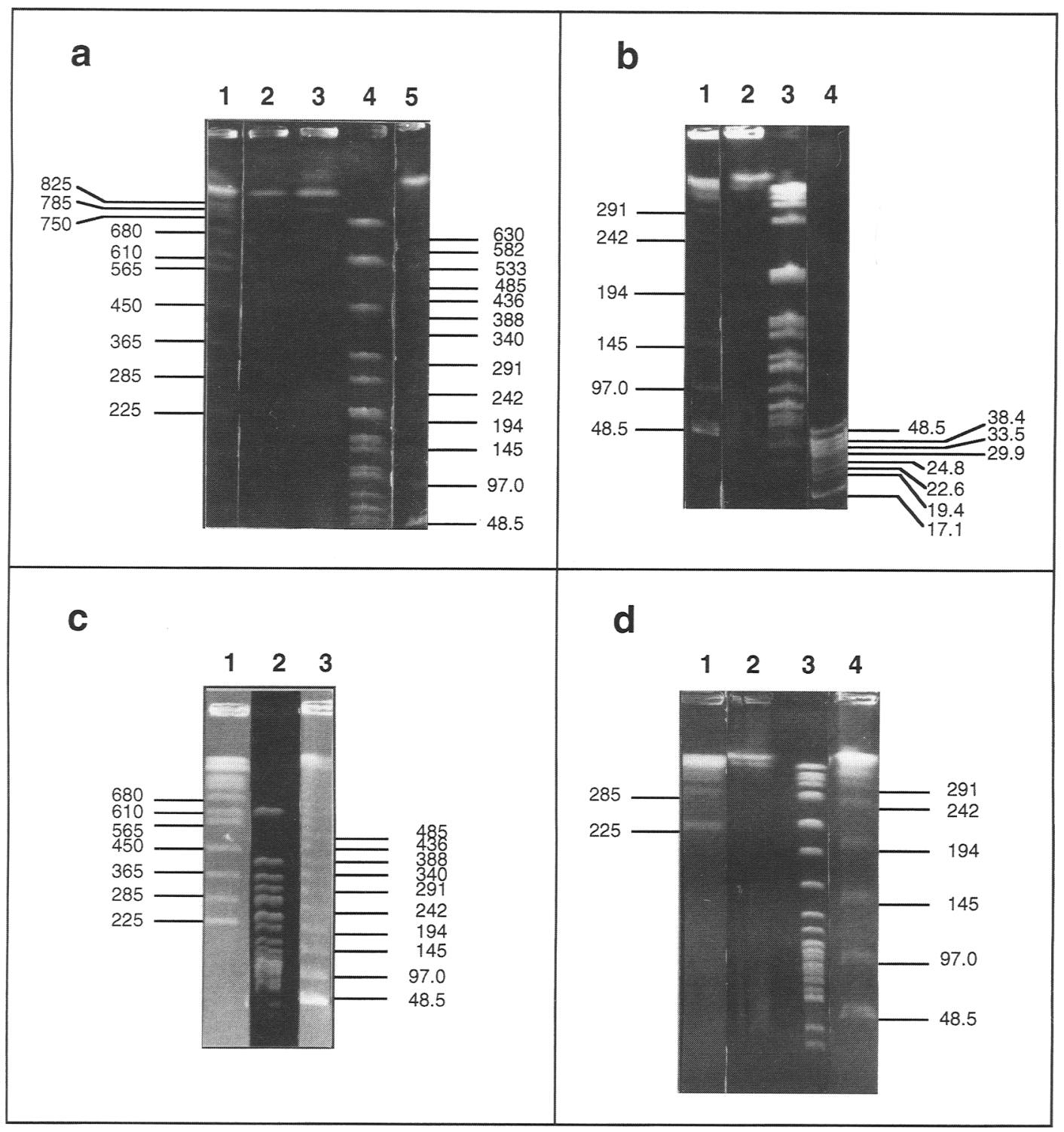

Figure 2 Sizing of the P. haloplanktis genome by digestion with Notl and Sfil restriction endonucleases. Size standards are in $\mathrm{kb}$. All P. haloplanktis lanes are one-fifteenth high concentration. (a) Notl large fragments. PFGE protocol C (Table 1). (Lane 1) S. cerevisiae chromosomal DNA (size standard); (lane 2) P. haloplanktis (untreated); (lane 3) P. haloplanktis (Notl digestion buffer without enzyme); (lane 4) P. haloplanktis (Notl digest); (lane 5) bacteriophage $\lambda$ concatemers (size standard). (b) Notl small fragments. PFGE protocol D (Table 1). (Lane 1) Bacteriophage $\lambda$ concatemers (size standard); (lane 2) P. haloplanktis (Notl digestion buffer without enzyme); (lane 3) P. haloplanktis (Notl digestion); (lane 4) high-molecular-weight markers (size standard). (c) Sfil large fragments. PFGE protocol C (Table 1). (Lane 1) S. cerevisiae chromosomal DNA (standard size); (lane 2) $P$. haloplanktis (Sfil digest); (lane 3) bacteriophage $\lambda$ concatemers (size standard). (d) Sfil small bands. PFGE protocol E (Table 1). (Lane 1) S. cerevisiae chromosomal DNA (size standard); (lane 2) P. haloplanktis (Sfil digestion buffer without enzyme); (lane 3) P. haloplanktis (Sfil digest); (lane 4) bacteriophage $\lambda$ concatemers (size standard). 


\section{P. HALOPLANKTIS GENOME STRUCTURE}

separate all resulting bands from either digest, so several protocols designed to separate different DNA size ranges were developed (Table 1 ). We analyzed seven gels with a total of 20 lanes containing NotI-digested $P$. haloplanktis genomic DNA and five gels with a total of 13 lanes containing Sfil-digested $P$. haloplanktis DNA. Although these PFGE protocols were optimized, not every band within the appropriate size range for a protocol was visible in every lane owing to variability in loading and other interexperimental changes. Therefore, we averaged all of the sizes obtained for each band (Table 2). Many of the bands were sized with more than one size standard; each measurement was counted separately in the number of bands analyzed (Table 2). The total genome size was $3512 \pm 112 \mathrm{~kb}$ as determined with NotI and $3468 \pm 54.1 \mathrm{~kb}$ as determined with SfiI.

We analyzed five gels with a total of 20 lanes containing undigested $P$. haloplanktis genomic DNA. Although there was high variability in the relative position of the band corresponding to the larger replicon (measured as $2977.6 \pm 789.5$ $\mathrm{kb}$ ), the smaller replicon consistently gave a size of $800 \pm 9.32 \mathrm{~kb}$. By inference, the expected size of the large replicon is $-2690 \mathrm{~kb}$. The larger band varied in position relative to the size standards depending on run conditions. This is probably because its size is between the largest band on the

\section{Table 1. PFGE Protocols}

\begin{tabular}{|c|c|c|c|c|}
\hline \multicolumn{2}{|c|}{ Protocols $^{a}$} & $\begin{array}{l}\begin{array}{l}\text { Run time } \\
\text { (hr) }\end{array} \\
24\end{array}$ & $\begin{array}{c}\begin{array}{c}\text { Voltage } \\
\text { (V/cm) }\end{array} \\
1.5 \\
1.8\end{array}$ & $\begin{array}{l}\text { Switch time } \\
\text { (sec) }\end{array}$ \\
\hline$A^{b}$ & $\begin{array}{l}\text { Step } 1 \\
\text { Step } 2 \\
\text { Step } 3 \\
\text { Step } 4 \\
\text { Step } 5\end{array}$ & $\begin{array}{r}24 \\
24 \\
24 \\
24 \\
8\end{array}$ & $\begin{array}{l}1.5 \\
1.8 \\
2.4 \\
3.6 \\
4.8\end{array}$ & $\begin{aligned} 2500 & \\
1200 & \rightarrow 600 \\
600 & \rightarrow 300 \\
300 & \rightarrow 90 \\
90 & \rightarrow 5\end{aligned}$ \\
\hline B & $\begin{array}{l}\text { Step } 1 \\
\text { Step } 2\end{array}$ & $\begin{array}{l}24 \\
24\end{array}$ & $\begin{array}{l}4.8 \\
3.6\end{array}$ & $\begin{aligned} 5 & \rightarrow 90 \\
90 & \rightarrow 300\end{aligned}$ \\
\hline C & Step 1 & 24 & 4.8 & $90 \rightarrow 5$ \\
\hline $\begin{array}{l}D \\
E\end{array}$ & $\begin{array}{l}\text { Step } 1 \\
\text { Step } 1 \\
\text { Step } 2\end{array}$ & $\begin{array}{r}24 \\
16 \\
8\end{array}$ & $\begin{array}{l}4.8 \\
4.8 \\
4.8\end{array}$ & $\begin{array}{r}15 \\
15 \\
9\end{array}$ \\
\hline $\begin{array}{l}\text { BioR } \\
{ }^{b} \text { All } \\
\text { for } r \\
\text { Aga }\end{array}$ & $\begin{array}{l}\text { Is were } \\
\text { protoce } \\
\text { pe. }\end{array}$ & $\begin{array}{l}\text { at at } 12^{\circ} \mathrm{C} \text { i } \\
\text { An in } 1.0 \% \text { which w }\end{array}$ & $\begin{array}{l}\text { n a CHEF } \\
\text { BI Ultrapur } \\
\text { as run in } 0 .\end{array}$ & $\begin{array}{l}\text {-II system from } \\
\text { Agarose, except } \\
\% \text { IBI Ultrapure }\end{array}$ \\
\hline
\end{tabular}

Saccharomyces cerevisiae size standard $(2200 \mathrm{~kb})$ and the smallest band on the Schizosaccharomyces pombe size standard $(3500 \mathrm{~kb})$, and, therefore, minor variations in either of these markers, sample loading, or other error could lead to large variations in the size estimate for this band.

\section{S rDNA Hybridization to P. haloplanktis Genomic DNA}

To determine whether the ancillary band seen during the PFGE of undigested total $P$. haloplanktis genomic DNA harbored rRNA operons, we hybridized a $P$. haloplanktis $16 \mathrm{~S}$ rDNA PCR amplicon to a Southern blot of $E$. coli and P. haloplanktis total genomic DNA. As expected, there was strong hybridization to the single $E$. coli chromosomal DNA band. Visually, there was no hybridization to the smaller $P$. haloplanktis replicon, but there was obvious hybridization to the larger one (data not shown).

To determine whether the difference in hybridization intensity could simply be a reflection of the variance in the amount of DNA in the bands, a photograph of the ethidium bromidestained gel corresponding to the blot was digitized and the pixel intensity of the two bands was quantitated. The larger replicon stained $\sim 14$-fold more intensely than the smaller replicon. After hybridization with the $16 \mathrm{~S}$ rDNA probe, the phosphorimage of the blot was analyzed. We found that the hybridization to the larger replicon was a minimum of 40 times and a maximum of 200 times greater than the hybridization to the smaller replicon, depending on the value of the background subtraction. The difference in hybridization intensity was much greater than the difference in ethidium bromide staining, implying that the hybridization difference was attributable to factors other than the difference in the amount of DNA in the bands. This large difference in hybridization to the two bands is unlikely to be attributable to unequal transfer of the two bands during Southern blotting because, theoretically, the smaller replicon should transfer more efficiently than the larger. However, hybridization was stronger to the larger band than the smaller band.

\section{Notl Digestion of the Larger Replicon}

Two-dimensional PFGE (Cole and Saint Girons 1994) was used to further verify that the two 
LANOIL ET AL.

\begin{tabular}{|c|c|c|c|c|c|}
\hline \multicolumn{3}{|c|}{ Sfil } & \multicolumn{3}{|c|}{ Notl } \\
\hline band & size $(\mathbf{k b})$ & $\begin{array}{l}\text { number of } \\
\text { bands analyzed }\end{array}$ & band & size $(\mathbf{k b})$ & $\begin{array}{l}\text { number of } \\
\text { bands analyzed }\end{array}$ \\
\hline$A$ & $586 \pm 18.1$ & 12 & A & $711 \pm 8.70$ & 27 \\
\hline B & $395 \pm 9.67$ & 13 & B & $580 \pm 8.55$ & 29 \\
\hline C & $345 \pm 10.1$ & 17 & C & $438 \pm 6.42$ & 30 \\
\hline D & $312 \pm 10.8$ & 19 & $\mathrm{D}$ & $327 \pm 6.10$ & 31 \\
\hline E & $266 \pm 7.61$ & 25 & $E$ & $277 \pm 4.89$ & 31 \\
\hline $\mathrm{F}$ & $226 \pm 7.77$ & 23 & $\mathrm{~F}$ & $217 \pm 7.21$ & 20 \\
\hline G & $192 \pm 6.25$ & 11 & G & $171 \pm 2.42$ & 14 \\
\hline $\mathrm{H}$ & $162 \pm 4.99$ & 12 & $\mathrm{H}$ & $159 \pm 1.91$ & 13 \\
\hline 1 & $140 \pm 9.96$ & 10 & 1 & $130 \pm 1.29$ & 14 \\
\hline J & $123 \pm 7.47$ & 8 & J & $119 \pm 1.53$ & 13 \\
\hline K & $109 \pm 2.67$ & 8 & $\mathrm{~K}$ & $93.2 \pm 1.69$ & 13 \\
\hline $\mathrm{L}$ & $104 \pm 2.66$ & 6 & $L$ & $73.0 \pm 1.22$ & 13 \\
\hline $\mathrm{M}$ & $98.3 \pm 2.06$ & 7 & $\mathrm{M}$ & $60.8 \pm 1.64$ & 5 \\
\hline $\mathrm{N}$ & $91.7 \pm 2.87$ & 6 & $N$ & $54.7 \pm 0.55$ & 4 \\
\hline $\mathrm{O}$ & $84.0 \pm 3.16$ & 6 & $\mathrm{O}$ & $33.5 \pm N D^{a}$ & 1 \\
\hline$P$ & $76.3 \pm 2.14$ & 7 & $P$ & $24.7 \pm N D$ & 1 \\
\hline Q & $67.2 \pm 1.79$ & 9 & & & \\
\hline $\mathrm{R}$ & $61.0 \pm 1.79$ & 6 & & & \\
\hline$S$ & $42.0 \pm N D$ & 1 & & & \\
\hline $\mathrm{T}$ & $31 \pm N D$ & 1 & & & \\
\hline Total & $3512 \pm 112$ & $N D^{a}$ & Total & $3468 \pm 54.1$ & $N D^{a}$ \\
\hline
\end{tabular}

bands constituted separate replicons. The first dimension was undigested $P$. haloplanktis total genomic DNA (e.g., Fig. 1b). The bands constituting the two replicons and a higher molecular weight band often seen just below the well (JBW) were excised from this gel, digested with NotI, and run in a second dimension (Fig. 3). We were unable to obtain enough DNA from the smaller replicon to see the digested fragments in the second dimension. However, we did visualize both the JBW digest and the larger replicon digest. The banding pattern for these digests was identical (Fig 3, lanes 4,6), demonstrating that these two bands are different conformers of the larger replicon.

Comparison of the banding pattern of the NotI-digested 2700-kb replicon to NotI-digested total genomic DNA revealed a band of $\sim 650 \mathrm{~kb}$ that was present in the total genomic DNA digest but was missing from the large-replicon-alone digest (Fig. 3, lanes 3,4,6, see arrowhead). This band accounts for $\sim 80 \%$ of the size of the smaller rep- licon. Presumably, the other $20 \%$ is found in lower molecular weight bands that we were unable to detect.

\section{DISCUSSION}

Digestions of $P$. haloplanktis total genomic DNA with NotI or $S f i$ indicated a genome size of $\sim 3500$ $\mathrm{kb}$ (Fig. 2; Table 2). This genome size was consistently observed over a large number of repetitions and measurements. Although it has been suggested that marine bacteria have small genomes (Robertson and Button 1989; Button et al. 1993), the genome size of $P$. haloplanktis falls near the middle of the range for bacteria, which range from $600 \mathrm{~kb}$ (Mycoplasma genitalium) to $9450 \mathrm{~kb}$ (Myxococcus xanthus) as measured by PFGE (for review, see Cole and Saint Girons 1994). The most abundant marine bacteria, unlike $P$. haloplanktis, cannot be cultured by traditional methods (Giovannoni et al. 1990); therefore, P. haloplanktis may not be typical of marine bacterio- 


\section{P. HALOPLANKTIS GENOME STRUCIURE}

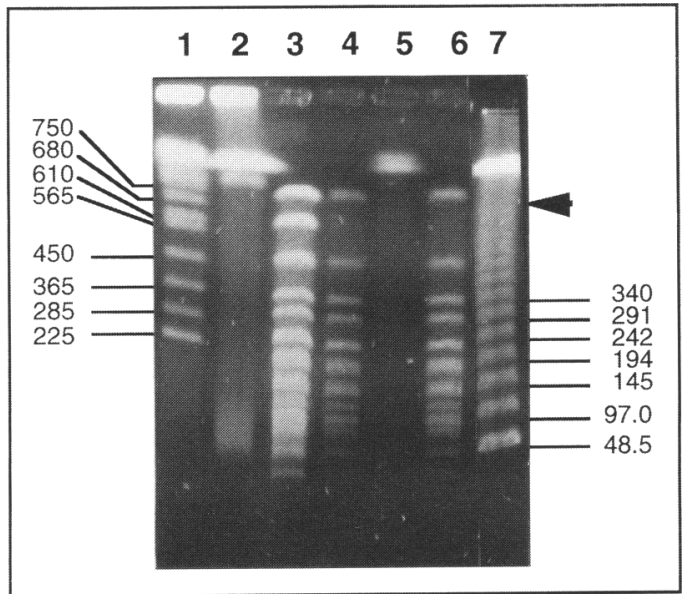

Figure 3 Two-dimensional PFGE of $P$. haloplanktis DNA. Size standards are in kb. First dimension: PFGE protocol B (Table 1). Second dimension: PFGE protocol C (Table 1). (Lane 1) S. cerevisiae chromosomal DNA (size standard); (lane 2) P. haloplanktis (Notl digestion buffer minus enzyme, one-fifteenth high concentration); (lane 3) P. haloplanktis (Notl digested, one-fifteenth high concentration); (lane 4) JBW band (Notl digested, one-fifth high concentration); (lane 5) 2700-kb replicon (Notl digestion buffer minus enzyme, one-fifth high concentration); (lane 6) 2700-kb replicon (Notl digested, one-fifth high concentration); (lane 7$)$ bacteriophage $\lambda$ concatemers (size standard). Lane 3 contains an $\sim 650$ $\mathrm{kb}$ band that is not present in lanes 4 and 6 (arrowhead).

plankton. However, there is evidence that $P$. haloplanktis has a ubiquitous distribution in marine systems, and, therefore, it is one of the best examples of a marine bacterioplankton species available for study in culture (Mullins et al. 1995).

Three DNA bands consistently were observed by PFGE of $P$. haloplanktis undigested total genomic DNA (Fig. 1a,b), whereas two bands were visualized with $E$. coli AB1157 (Fig. 1a). Only one band was expected for $E$. coli AB1157, because this organism has only one chromosome and does not carry any plasmids. The band seen just below the well (JBW) had an apparent size much greater than the reported size of the E. coli K-12 chromosome (4700 bp; Smith et al. 1987). Because large circular DNA migrates only poorly through pulsed-field gels (Chu and Gunderson 1991; Gunderson and Chu 1991), we hypothesized that the JBW bands observed in both $E$. coli and $P$. haloplanktis lanes were circular conformers of the chromosome. This was confirmed by two- dimensional PFGE, which demonstrated that the JBW band and the $2700-\mathrm{kb}$ band had identical restriction fragment banding patterns (Fig. 3, lanes 4,6).

The presence of the third band in the $P$. haloplanktis undigested genomic DNA implied the presence of a second large replicon. This conclusion was confirmed by comparisons to NotI digests of $P$. haloplanktis total genomic DNA, which revealed a band that was missing in digests of the $2700-\mathrm{kb}$ or JBW bands (Fig. 3, see arrowhead). This band accounted for $\sim 80 \%$ of the size of the smaller replicon as determined by PFGE of undigested $P$. haloplanktis DNA. Another piece of evidence indicating the presence of a second large replicon was $16 \mathrm{~S}$ rDNA hybridization, which was much stronger for the larger replicon than for the smaller. Although part of the definition of a chromosome is that it carries essential housekeeping genes (Holloway 1993), the lack of a gene encoding 16S rRNA does not exclude a chromosomal function for the smaller $P$. haloplanktis replicon. Other housekeeping functions may yet be ascribed to the $800-\mathrm{kb}$ replicon.

The observed 14-fold difference in the ethidium bromide fluorescence of the large and small replicons was greater than the value of 3.4 predicted from the ratio of the estimated molecular weights. This can be accounted for in three ways: (1) The $2700-\mathrm{kb}$ replicon is always found in at least fourfold stoichiometry over the $800-\mathrm{kb}$ replicon; (2) there were measurement errors owing to overlap between the JBW band and larger replicon; (3) double-stranded breaks are more likely to occur in the larger replicon because of its 3.4-fold greater size. Possibility 3 is the most likely explanation. The bands we observed are probably linearized versions of circular molecules. Assuming that the larger replicon is 3.4 times more likely to have fortuitous doublestranded breaks leads to an estimate of a 1:1.2 stoichiometry between the two replicons from the ethidium bromide fluorescence data. It also implies a circular nature for both bands in vivo, which is supported by the observation of different conformers of the larger $P$. haloplanktis replicon described above.

Suzuki and colleagues (1994) used PFGE to examine the genome of $P$. haloplanktis and several other, closely related organisms. Although they were unable to size the genomes of $P$. haloplanktis or Pseudoalteromonas espejiana, they reported the size of the genomes of Pseudoalteromonas nigrifaciens (2040 kb), Pseudoalteromonas sp. 
M-1 (2240 kb), and Shewanella putrefaciens (2383 $\mathrm{kb})$. The larger replicon of $P$. haloplanktis $(-2700$ $\mathrm{kb})$ is close to the size range of the chromosomes of other Pseudoalteromonas spp. These data suggest that other organisms of the same genus do not carry the second $(800-\mathrm{kb})$ genomic element. However, they did not report the banding pattern for undigested total genomic DNA of these species; therefore, it is unknown whether these congeners carry a second large replicon. Unlike Suzuki and colleagues (1994), we encountered no endogenous DNase activity that leads to random digestion of DNA in $P$. haloplanktis.

The $P$. haloplanktis genome organization is complex, consisting of two large, independent replicons. The nature of these replicons and their function is unknown. Many prokaryotes carry large genetic elements that code for important metabolic functions. These have been called megaplasmids because they resemble plasmids in transfer functions, copy number variability, and lack of essential housekeeping functions (Holloway 1993). Recently, however, multiple chromosomes have been described in five different bacterial species. The size of the "extra" chromosomes range from $350 \mathrm{~kb}$ in the case of Leptospira interrogans (Zuerner 1991; Zuerner et al. 1993) to $2500 \mathrm{~kb}$ in the case of Pseudomonas cepacia 17616 (Cheng and Lessie 1994) (Table 3). A mathematical model has been proposed that explains the selective advantage of maintaining the genome in multiple, smaller replicons rather than a single, larger replicon (Stouthamer and Kooijman 1993).

The line separating megaplasmids from chromosomes is vague; therefore, in this study we use the term "replicon." One current definition of a chromosome is an independent genetic element that carries essential housekeeping genes, is consistently present in all strains of a species, is nontransferable, and is present in a constant stoichiometric relationship with other chromosomal elements (Holloway 1993). By these criteria, neither the smaller replicon nor the larger replicon of $P$. haloplanktis were proven to be chromosomes.

P. haloplanktis is the first marine bacterium shown to have a complex genome structure consisting of more than one large genetic unit. The relevance of unusual genome structures such as those seen in this study to the functioning of cells in nature is not understood. They may have considerable implications in the study of microbial ecology, including measurement of genome sizes, gene copy number estimates, and determination of metabolic capabilities of bacterioplankton.

\section{METHODS}

\section{Strains and Growth Conditions}

P. haloplanktis was obtained from the American Type Culture Collection (catalog no. 14393). E. coli AB1157 was a gift from L. Walter Ream (Dept. of Agricultural Chemistry, Oregon State University, OR). P. haloplanktis was cultured at $30^{\circ} \mathrm{C}$ in $100 \mathrm{ml}$ of $1 / 2$ SWPYGR medium [20 ml/liter of Hutner's mineral base (Atlas 1993), $0.25 \mathrm{~g} /$ liter of Dglucose, $0.25 \mathrm{~g} /$ liter of Difco peptone, $0.25 \mathrm{~g} /$ liter of Difco yeast extract, $0.25 \mathrm{~g} /$ liter of ribose, $0.25 \mathrm{ml} /$ liter of VA vitamin solution (Atlas 1993), $500 \mathrm{ml} / \mathrm{liter}$ of $0.2-\mu \mathrm{m}$ filtersterilized seawater]. Cells were grown to a density of of $\sim 2 \times 10^{8}$ cells $/ \mathrm{ml}$ and were pelleted by centrifugation at $5000 \mathrm{~g}$ for $5 \mathrm{~min}$ at $4^{\circ} \mathrm{C}$.

\section{Lysis and Deproteination}

Cells were embedded in agarose plugs as described by Smith and Condemine (1990), with minor modifications. Briefly, cells were embedded in $0.7 \%$ InCert agarose (FMC, Rockland, ME) or IBI Ultrapure low melting point agarose (IBI, New Haven, CT). These plugs were treated with a lysis buffer [50 mM NaCl, $10 \mathrm{~mm}$ Tris (pH7.5), $100 \mathrm{~mm}$ ethylene diamine tetraacetic acid (EDTA) (pH 8.0), 0.5\% NaSarkosyl (Sigma); and $1 \mathrm{mg} / \mathrm{ml}$ of lysozyme (Sigma)] overnight at $37^{\circ} \mathrm{C}$. The buffer was then changed to freshly made DB 0.5 [0.5 mM EDTA (pH 8.0); 1.0\% NaSarkosyl (Sigma); $0.5 \mathrm{mg}$ / $\mathrm{ml}$ of proteinase K (Sigma)] and further incubated for $24 \mathrm{hr}$ at $37^{\circ} \mathrm{C}$. Treated plugs were washed for at least $24 \mathrm{hr}$ with at least three buffer changes in 0.5 M EDTA (pH 8.0). Agarose plugs could be stored in $50 \mathrm{~mm}$ EDTA $(\mathrm{pH} 8.0)$ at $4^{\circ} \mathrm{C}$ for up to 6 months with no detectable degradation of the DNA. Our baseline concentration (called "high concentration") was $2.5 \times 10^{10}$ cells $/ \mathrm{ml}$. We used various dilutions of this baseline for different applications as described.

\section{Restriction Digestion}

Plugs were equilibrated in $1 \mathrm{ml}$ of Tris-EDTA (TE) for 15 min at room temperature, followed by two equilibrations of $15 \mathrm{~min}$ each in $300 \mathrm{ml} 1 \times$ restriction buffer plus 0.1 $\mathrm{mg} / \mathrm{ml}$ of acetylated bovine serum albumin (BSA). Forty units of enzyme were added to the buffer, and the mix was incubated overnight at $37^{\circ} \mathrm{C}$ with gentle agitation. The reaction was stopped by the addition of $0.5 \mathrm{M}$ EDTA $(\mathrm{pH}$ 8.0 ) to a final concentration of $50 \mathrm{~mm}$. The plugs were stored in this solution at $4^{\circ} \mathrm{C}$ until use, up to 1 week.

\section{PFGE of DNA}

PFGE was performed in a CHEF-DRII apparatus (Bio-Rad, Hercules, CA) in $0.5 \times$ Tris/borate/EDTA buffer (TBE) at $12^{\circ} \mathrm{C}$. PFGE protocols are described in Table 1. S. pombe, $S$. cerevisiae, concatemers of bacteriophage $\lambda$ DNA, and highmolecular-weight DNA markers (Bio-Rad) were used in 
Table 3. Examples of Prokaryotic Organisms That Have Multiple Large Replicons Including the Sizes of Each Replicon

\begin{tabular}{|c|c|c|c|c|c|}
\hline \multirow[b]{3}{*}{ Organism } & \multicolumn{3}{|c|}{ Genome size } & \multirow[b]{3}{*}{ Notes } & \multirow[b]{3}{*}{ Reference } \\
\hline & \multirow{2}{*}{$\begin{array}{l}\text { total } \\
(\mathbf{k b})\end{array}$} & \multicolumn{2}{|c|}{ individual replicons (kb) } & & \\
\hline & & chromosome(s) & megaplasmid(s) & & \\
\hline $\begin{array}{l}\text { Rhodobacter } \\
\text { sphaeroides }\end{array}$ & 3960 & $\begin{array}{l}\text { Chromosome I: } 3046 \\
\text { Chromosome II: } 914\end{array}$ & None & $\begin{array}{l}\text { Multiple } \\
\text { chromosomes } \\
\text { first discovered } \\
\text { and best } \\
\text { studied }\end{array}$ & $\begin{array}{l}\text { Suwanto and } \\
\text { Kaplan } \\
\text { 1989, } 1992\end{array}$ \\
\hline $\begin{array}{l}\text { Agrobacterium } \\
\text { tumefasciens } \\
\text { C58 }\end{array}$ & 5750 & $\begin{array}{l}\text { Circular } \\
\text { chromosome: } 3000 \\
\text { Linear } \\
\quad \text { chromosome: } 2100\end{array}$ & $\begin{array}{l}\text { Cryptic plasmid: } 450 \\
\text { Ti plasmid: } 200\end{array}$ & $\begin{array}{l}\text { Interdomain } \\
\text { genetic } \\
\text { transfer }\end{array}$ & $\begin{array}{l}\text { Allardet-Servent } \\
\text { et al. } 1993\end{array}$ \\
\hline $\begin{array}{l}\text { Leptospira } \\
\text { interrogans }\end{array}$ & $\begin{array}{l}4750 \\
\text { to } \\
4950\end{array}$ & $\begin{array}{l}\text { Chromosome 1: } 4400 \\
\quad \text { to } 4600 \\
\text { Chromosome 2: } 350\end{array}$ & None & $\begin{array}{l}\text { Spirochete, } \\
\text { human and } \\
\text { animal } \\
\text { pathogen }\end{array}$ & $\begin{array}{l}\text { Zuerner 1991; } \\
\text { Zuerner et } \\
\text { al. } 1993\end{array}$ \\
\hline $\begin{array}{l}\text { Brucella } \\
\text { melitensis 16M }\end{array}$ & 3250 & $\begin{array}{l}\text { Chromosome I: } 2100 \\
\text { Chromosome II: } 1150\end{array}$ & None & $\begin{array}{l}\text { Human and } \\
\text { animal } \\
\text { pathogen }\end{array}$ & $\begin{array}{l}\text { Michaux et al. } \\
1993\end{array}$ \\
\hline $\begin{array}{l}\text { Pseudomonas } \\
\text { cepacia } 17616\end{array}$ & 7000 & $\begin{array}{l}\text { Chromosome I: } 3400 \\
\text { Chromosome II: } 2500 \\
\text { Chromosome III: } 900\end{array}$ & Cryptic plasmid: 170 & $\begin{array}{l}\text { Bioremediative } \\
\text { organism }\end{array}$ & $\begin{array}{l}\text { Cheng and } \\
\text { Lessie } 1994\end{array}$ \\
\hline $\begin{array}{l}\text { Rhizobium } \\
\text { meliloti }\end{array}$ & 6500 & Chromosome: 3400 & $\begin{array}{l}\text { pSym-b: } 1700 \\
\text { pSym-a: } 1400\end{array}$ & $\begin{array}{r}\text { Nodulating } \\
\text { organism }\end{array}$ & $\begin{array}{l}\text { Sobral et al. } \\
1991\end{array}$ \\
\hline $\begin{array}{l}\text { Haloferax } \\
\text { mediterranei }\end{array}$ & 3840 & Chromosome: 2900 & $\begin{array}{l}\text { pHM500: } 490 \\
\text { pHM300: } 320 \\
\text { pHM100: } 130\end{array}$ & Archaeon & $\begin{array}{r}\text { Lopez-Garcia } \\
\text { et al. } 1994\end{array}$ \\
\hline $\begin{array}{l}\text { Alcaligenes } \\
\text { eutrophus }\end{array}$ & $N D^{a}$ & Chromosome: ND ${ }^{\mathrm{a}}$ & $\begin{array}{l}\text { pHG1: } 450 \\
\text { pMOL28: } 163 \\
\text { pMOL30: } 238\end{array}$ & $\begin{array}{l}\text { Bioremediative } \\
\text { organism }\end{array}$ & $\begin{array}{l}\text { Mergeay et al. } \\
1985 ; \\
\text { Freidrich et } \\
\text { al. } 1986\end{array}$ \\
\hline $\begin{array}{l}\text { Anabaena spp. } \\
\text { Strain PCC } \\
7120\end{array}$ & 7110 & Chromosome: 6400 & $\begin{array}{l}\alpha \text { Megaplasmid: } 410 \\
\beta \text { Megaplasmid: } 190 \\
\gamma \text { Megaplasmid: } 110\end{array}$ & $\begin{array}{l}\text { Provided first } \\
\text { evidence of } \\
\text { genetic } \\
\text { transfer } \\
\text { between } \\
\text { cyanobacteria }\end{array}$ & $\begin{array}{l}\text { Bancroft et al. } \\
\text { 1989; } \\
\text { Muro-Pastor } \\
\text { et al. } 1994\end{array}$ \\
\hline
\end{tabular}

All prokaryotes with multiple chromosomes reported to date are presented. Examples of organisms with megaplasmids are also presented.

${ }^{\mathrm{a} N D}$ : not determined.

various commbinations as size markers. Gels were stained with ethidium bromide $(10 \mu \mathrm{g} / \mathrm{ml})$ and photographed. Photographs were digitized with a Hewlett-Packard ScanJet IIc digital scanner. Sizing of the bands in the digitized images was performed with the FragmeNT analysis program (Molecular Dynamics, Sunnyvale, CA). In all figures, data in an individual panel are derived from a single gel.

\section{Two-dimensional PFGE}

The first dimension of the two-dimensional PFGE (Cole and Saint Girons 1994) was electrophoresis of agarose plugs containing $P$. haloplanktis total genomic DNA using protocol A or B (Table 1). End lanes were cut away from the rest of the gel, stained with ethidium bromide $(10 \mu \mathrm{g} / \mathrm{ml})$, and photographed with a ruler. The end lanes were used as templates for excision of unstained bands. Following excision, the unstained bands were digested with the restriction endonuclease NotI as described above. The second dimension was electrophoresis of these plugs with PFGE protocol C (Table 1) after restriction digestion. 


\section{LANOIL EI AL.}

\section{Southern Blotting}

Gels were photographed with a ruler and then blotted by the alkaline transfer method (Sambrook et al. 1989) onto Zeta-probe membranes (Bio-Rad). Blots were baked for 30 min at $80^{\circ} \mathrm{C}$ and then UV cross-linked with $1200 \mu \mathrm{J}$ in an Ultra-Lum UVC-515 ultraviolet cross-linker (Ultra-Lum, Inc., Carson, CA) to fix the DNA to the membrane.

\section{Probe Synthesis}

rDNA probes were made by PCR amplification (Saiki et al. 1988) of $P$. haloplanktis rDNA. DNA was extracted from a single colony by boiling for $5 \mathrm{~min}$ in $10 \mathrm{ml}$ of a TAPS buffer [5 mM TAPS ( $N$-tris \{hydroxymethyl\} methyl-3-aminopropanesulfonic acid; Sigma), $50 \mathrm{~mm} \mathrm{KCl}, 0.1 \%$ Tween 20 (Sigma)], which assisted in cell lysis. Small-subunit ribosomal primers for the domain Bacteria (sensu Woese), 27F (AAGGAGGTGATCCANCCRCA) and 1518R (AGAGTTTGATCMTGGCTCAG) were used (Giovannoni 1991). The reaction conditions were $0.2 \mathrm{~mm}$ dNTPs (Stratagene, La Jolla, CA), $0.2 \mathrm{~mm}$ each primer, $10 \%$ acetamide, $6 \mathrm{~mm}$ $\mathrm{MgCl}_{2}, 1 \mathrm{ml}$ of TAPS lysis supernatant, $1 \times$ buffer [50 mM $\mathrm{KCl}, 10 \mathrm{~mm}$ Tris- $\mathrm{HCl}\left(\mathrm{pH} 9.0\right.$ at $\left.25^{\circ} \mathrm{C}\right), 0.1 \%$ Triton $\mathrm{X}-100$ ], and 2.5 units of Taq polymerase (Promega, Madison, WI) in a final reaction volume of $100 \mu \mathrm{l}$. Cycles were $96^{\circ} \mathrm{C}, 1$ min; $55^{\circ} \mathrm{C}, 1.5 \mathrm{~min} ; 72^{\circ} \mathrm{C}, 3 \mathrm{~min}$; for 35 cycles. All reactions were performed on an MJ Research PTC-100 thermal cycler (MJ Research, Inc., Watertown, MA).

\section{Probe Labeling and Hybridization}

Probes were radioactively labeled with a random priming DNA labeling kit (U.S.Biochemical, Cleveland, $\mathrm{OH}$ ) by the manufacturer's instructions with $\left[\alpha-{ }^{32} \mathrm{P}\right] \mathrm{dCTP}(3000 \mathrm{Ci} /$ mmole; DuPont, Boston, MA). Blots were prehybridized by the membrane manufacturer's recommendations in a Techne HB-1 hybridization oven (Techne Incorporated, Princeton, NJ). Hybridization was carried out at $65^{\circ} \mathrm{C}$ overnight with $5 \times 10^{7}$ to $10 \times 10^{7} \mathrm{cpm}$ of probe. Washes were performed by the membrane manufacturer's recommendations (Bio-Rad) with a $70^{\circ} \mathrm{C}$ stringent wash. Hybridization was visualized with a Molecular Dynamics PhosphorImager and ImageQuant software.

\section{Analysis of rDNA Hybridization and Ethidium Bromide Stain Intensity}

A photograph of the ethidium bromide-stained gel, taken prior to blotting and probing, was digitized with a Hewlett-Packard ScanJet IIc digital scanner. Pixel intensities for the ethidium bromide-stained bands were measured and compared using NIH Image. A similar procedure was performed for the digitized phosphorimage of the blot.

\section{ACKNOWLEDGMENTS}

We especially thank Alan Bakalinsky for use of equipment. We thank L. Walter Ream for his gift of E. coli AB1157. We also thank Ena Urbach, Kate Field, Lisa Stein, and Kevin Vergin for critical reading of the manuscript. This work was supported by Department of Energy grant FG0693ER61697. B.D.L. was partially supported in this work by National Institutes of Health Virology Training Grant 5T32AI07379.

The publication costs of this article were defrayed in part by payment of page charges. This article must therefore be hereby marked "advertisement" in accordance with 18 USC section 1734 solely to indicate this fact.

\section{REFERENCES}

Allardet-Servent, A., S. Michaux-Charachon, E. Jumas-Bilak, L. Karayan, and M. Ramuz. 1993. Presence of one linear and one circular chromosome in the Agrobacterium tumefaciens C58 genome. J. Bacteriol. 175: 7869-7874.

Amann, R.I., W. Ludwig, and K.-H. Schleifer. 1995. Phylogenetic identification and in situ detection of individual microbial cells without cultivation. Microbiol. Rev. 59: 143-169.

Atlas, R.M. 1993. Handbook of microbiological media. CRC Press, Boca Raton, FL.

Bancroft, I., C.P. Wolk, and E.V. Oren. 1989. Physical and genetic maps of the genome of the heterocyst-forming cyanobacterium Anabaena sp. Strain PCC 7120. J. Bacteriol. 171: 5940-5948.

Baumann, P., M.J. Gauthier, and L. Baumann. 1984. The genus Alteromonas. In Bergey's manual of systematic bacteriology (ed. N.R. Krieg), pp. 343-352. Williams \& Wilkins, Baltimore, MD.

Button, D.K., F. Schut, P. Quang, R. Martin, and B.R. Robertson. 1993. Viability and isolation of marine bacteria by dilution culture: Theory, procedures, and initial results. Appl. Environ. Microbiol. 59: 881-891.

Cheng, H. and T.G. Lessie. 1994. Multiple replicons constituting the genome of Pseudomonas cepacia 17616. J. Bacteriol. 176: 4034-4042.

Chu, G. and K. Gunderson. 1991. Separation of large DNA by a variable-angle contour-clamped homogenous electric field apparatus. Anal. Biochem. 194: 439-446.

Cole, S.T. and I. Saint Girons. 1994. Bacterial genomics. FEMS Microbiol. Rev. 14: 139-160.

Farrelly, V., F.A. Rainey, and E. Stackebrandt. 1995. Effect of genome size and rrn gene copy number on PCR amplification of $16 \mathrm{~S}$ rRNA genes from a mixture of bacterial species. Appl. Environ. Microbiol. 61: 2798-2801.

Friedrich, B., C. Kortluke, C. Hogrefe, G. Eberz, B. Silber, and J. Warrelmann. 1986. Genetics of hydrogenase from aerobic lithoautotrophic bacteria. Biochimie 68: 133-145.

Gauthier, G., M. Gauthier, and R. Christen. 1995. Phylogenetic analysis of the genera Alteromonas, Shewanella, and Moritella using genes coding for 


\section{P. HALOPLANKTIS GENOME STRUCTURE}

small-subunit rRNA sequences and division of the genus Alteromonas into two genera, Alteromonas (emended) and Pseudoalteromonas gen. nov., and proposal of twelve new species combinations. Int. J. System. Bacteriol.

45: $755-761$.

Giovannoni, S.J. 1991. The polymerase chain reaction. In Sequencing and hybridization techniques in bacterial systematics (ed. E. Stackebrandt and M. Goodfellow), pp. 177-201. John Wiley \& Sons, New York, NY.

Giovannoni, S.J., T.B. Britschgi, C.L. Moyer, and K.G. Field. 1990. Genetic diversity in Sargasso Sea bacterioplankton. Nature 345: 60-63.

Gunderson, K. and G. Chu. 1991. Pulsed-field electrophoresis of megabase-sized DNA. Mol. Cell. Biol. 11: $3348-3354$.

Holloway, B.W. 1993. Genetics for all bacteria. Annu. Rev. Microbiol. 47: 659-684.

Lopez-Garcia, P., J. Anton, J.P. Abad, and R. Amils. 1994. Halobacterial megaplasmids are negatively supercoiled. Mol. Microbiol. 11: 421-427.

Mergeay, M., D. Nies, H.G. Schlegel, J. Geritis, P. Charles, and F. Van Gijsegem. 1985. Alcaligenes eutrophus $\mathrm{CH} 34$ is a facultative chemolithotroph with plasmid-bound resistance to heavy metals. J. Bacteriol. 162: 328-334.

Michaux, S., J. Paillisson, M. Carles-Nurit, G. Bourg, A. Allardet-Servent, and M. Ramuz. 1993. Presence of two independent chromosomes in the Brucella melitenis $16 \mathrm{M}$ genome. J. Bacteriol. 175: 701-705.

Mullins, T.D., T.B. Britschgi, R.L. Krest, and S.J. Giovannoni. 1995. Genetic comparisons reveal the same unknown bacterial lineages in Atlantic and Pacific bacterioplankton communities. Limnol. Oceanogr. 40: $148-158$.

Muro-Pastor, A.M., T. Kuritz, E. Flores, A. Herrero, and C.P. Wolk. 1994. Transfer of a genetic marker from a megaplasmid of Anabaena sp. strain PCC7120 to a megaplasmid of a different Anabaena strain. J. Bacteriol. 176: $1093-1098$.

Robertson, B.R. and D.K. Button. 1989. Characterizing aquatic bacteria according to population, cell size, and apparent DNA content by flow cytometry. Cytometry 10: $70-76$.

Saiki, R.K., D.H. Gelfand, S. Stoffel, S.J. Scharf, R. Higuchi, G.T. Horn, K.B. Mullis, and H.A. Erlich. 1988. Primer-directed enzymatic amplification of DNA with a thermostable DNA polymerase. Science 239: 487-491.

Sambrook, J., E.F. Fritsch, and T. Maniatis. 1989.

Molecular cloning: A laboratory manual, 2nd edition. Cold Spring Harbor Laboratory Press, Cold Spring Harbor, NY.

Smith, C.L. and G. Condemine. 1990. New approaches for physical mapping of small genomes. J. Bacteriol. 172: $1167-1172$.

Smith, C.L., J.G. Econome, A. Schutt, S. Klco, and C.R. Cantor. 1987. A physical map of the Escherichia coli K12 genome. Science 236: 1448-1453.

Sobral, B.W.S., R.J. Honeycutt, A.G. Atherly, and M. McClelland. 1991. Electrophoretic separation of the three Rhizobium meliloti replicons. J. Bacteriol. 173: $5173-5180$.

Stein, J.L., T.L. Marsh, K.Y. Wu, H. Shiuza, and E.F. DeLong. 1996. Characterization of uncultivated prokaryotes: Isolation and analysis of a 40-kilobase pair genome fragment from a planktonic marine archaeon. $J$. Bacteriol. 178: 591-599.

Stouthamer, A.H. and S.A. Kooijman. 1993. Why it pays for bacteria to delete disused DNA and to maintain megaplasmids. Antonie-Van-Leeuwenhoek 63: 39-43.

Suwanto, A. and S. Kaplan. 1989. Physical and genetic mapping of the Rhodobacter sphaeroides 2.4.1T genome: Presence of two unique circular chromosomes. $J$. Bacteriol. 171: 5850-5859.

1992. Chromosome transfer in Rhodobacter spaeroides: Hfr formation and genetic evidence for two unique circular chromosomes. J. Bacteriol.

174: $1135-1145$.

Suzuki, S., K. Kita-Tsukamoto, and T. Fukagawa. 1994. The 16S rRNA sequence and genome sizing of tributyltin resistant marine bacterium, strain M-1. Microbios 77: 101-109.

Zuerner, R.L. 1991. Physical map of chromosomal and plasmid DNA comprising the genome of Leptospira interrogans. Nucleic Acids Res. 19: 4857-4860.

Zuerner, R.L., J.L. Herrmann, and I. Saint Girons. 1993. Comparison of genetic maps for two Leptospira interrogans serovars provides evidence for two chromosomes and intraspecies heterogeneity. J. Bacteriol. 175: 5445-5451.

Received June 21, 1996; accepted in revised form October 3, 1996. 


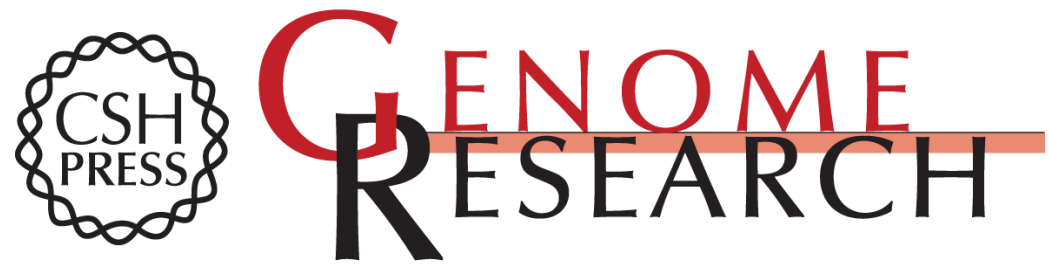

\section{The marine bacterium Pseudoalteromonas haloplanktis has a complex genome structure composed of two separate genetic units.}

B D Lanoil, L M Ciuffetti and S J Giovannoni

Genome Res. 1996 6: 1160-1169

Access the most recent version at doi:10.1101/gr.6.12.1160

References This article cites 30 articles, 18 of which can be accessed free at: http://genome.cshlp.org/content/6/12/1160.full.html\#ref-list-1

\section{License}

Email Alerting

Receive free email alerts when new articles cite this article - sign up in the box at the Service top right corner of the article or click here.

\section{Affordable, Accurate Sequencing.}

